$\mathrm{f}$ the south-east being a prolongation of those of Wales. Later in date as regards the underground movements that determined their site, are the mountainous ridges of Kerry and Cork. These are local uplifts which, though on a small scale, are by far the best examples in Britain of true mountain structure. The old Red Sandstone and Carboniferous rocks have there been thrown into broad f,lds and troughs which run in a general east and we-t direction. In some cases, as in the Knockmealdown Mountain, the arch is composed entirely of Old Red Sandstone flanked with Carboniferous strata. But in most instances an underlying wedge of Lower Silurian rocks has been driven through the arch. As not only the Carboniferous Limestone, but the rest of the Carboniferous system covered the south of Ireland and participated in this plication, the amount of denudation from these ridges has been enormous. On the Galty range, for example, it can hardly have been le:s but may have been more than 12,000 feet. The third and late:t group of Irish mountains is that of Mourne and Carlingf.rrd, which may with some probability be referred to older Tertiary time when the similar granitic and porphyritic masses in Mull and Skye were erupted.

The tablelands of Britain strictly include the mountains, which are in general only prominences carved out of tablelands. But there are still large areas in which the plateau character is well shown. Of these the most extensive and in many respect the most interesting is the pesent tableland or plain of Central Ireland. As now exposed, this region lies upon an undulating eroded surface of Carboniferous Limestone. But it was formerly covered by at least 3000 or 4000 feet more of Carboniferous strata, as can be shown by the fragnents that remain. The present system of drainage across the centre of Ireland took it; ori jin ling befure the ancient tableland had been reduced to its present level, and before some of the ridges, now prominent, had been exposed to the light. The Moors and Wolds of Yorkshire present us with a fragment of a tableland conposed of nearly horizontal Jurassic and Cretaceous rocks. The Lammermuir Hills and Southern Uplands of Scotland form a broad tableland which has been formed on a deeply eroded surface of Lower Silurian rocks.

\section{THE MONK FISH}

NATUREN has recently supplied its readers with some interesting details concerning the so-called "monk-fish" of the Sound, which may be regarded as the genuine forerunner of the sea-serpent of modern times. Its capture and appearance were deemed worthy of record in Arild Hirtfeld's great "History of Denmark," published in I595, while portraits of the sea-monk embellished the works of various Scandinavian and German natural history writers of the middle of the sixteenth century. Among these, Guillaume Rondelet, in his great folio work, "Libri de Piscibus Marinis," first claimed the special privilege of giving to the world a facsimile of the authentic likeness of the monk. This, we are assured, bad been taken from life for, and in the presence of, a nobleman, who had caused one copy to be made for the Emperor Charles V., and another for Margaret, Queen of Navarre, by whom it was presented to the author. Hirtfeld does not profe:s to have been brought into such close connection with the original, but he and the historians, Krag and Stephanius, agree in reporting that fish, bearing the semblance of a human head with a monk's shaven crown, and having torn or mutilated limbs indistinctly defined under a scaly covering, was, in the year 1550 , captured in the Sound, in a herring.fisher's net, and brought to the King of Denmark, who immediately gave orders that it should be buried de sp underground, " to hinder indiscreet talk among the ignorant, whose minds are always perturbed by what is new." The speedy burial of the monster did not allay the excitement caused by its apparition, and Rondelet found, to his extreme annoyance, that his Swiss friend, Gesner, and other philosophers then in Rome, were in possession of other reputed original likenesses of the monk, differing from his own. This circumstance, he admits, inclined him to suspect that the artist had added "this or that according to fancy to make the fish seem more wonderful than it was in reality." He even confesses that some of the portraits have no more resemblance to a human head than might be detected in a frog or a toad; that the extremities look like fins, and that the so-called monk's gown is more like a dark seal's skin than a scaly armour. From these and other corrections, coupled with Gesner's mention of a fish's tail having formed part of the monk's body, Prof. Steenstrup infers that the "monk-fish" was an unusually large specimen of the Loligo or Squid family, whose caudal extremity, bearing probably bruises or other marks on the skin, had acquired in the imagination of the spectators the semblance of a head and neck with torn-off arms, while the arms of the cephalopod had served to represent lacerated extrenities. A comparion of the numerous conflicting contemforaneous descriptions of the Danish "sea-monk" and of the later " Kraken" of the old Norwegian Bishop Pontoppidan might possibly be not wholly useless in the present day in checking an over hasty confidence in the truth of every fresh tale of encounters with sea-serpents, as recorded by credulous seafaring men. We may, in the meanwhile, refer all who are interested in sea-monsters to the July number of Naturen, in which they will find a faithful representation of Rondelet's monk-fish, while the September number of the same journal gives reproductions of two characteristic Japanese pictures, in one of which a solitary boatman is battling in a stormy sea with a formidable creature, evidently a highly magnified form of octopus, one of whose arms has been severed as it encircled man and boat, while the other arms are represented as striving to draw their prey nearer to the huge head with its protruding eyes. In the second picture, which, if less forcible, is more realistic, we see in the wondering and terrified expression of the assembled men and boys the surprise and alarm excited by the appearance at a fishmonger's stall of two octopus arms, not unlike suspended serpents. The terror of the spectacle has communicated itself to domestic animals-a dog hiding himself, while a cat is taking rapid flight up the roof of the house.

\section{UNIVERSITY AND EDUCATIONAL} INTELLIGENCE

OxFord. - The Examiners for the Radeliffe Travelling Fellowship give notice that the examination will commence on February 20 at $\mathrm{roa}_{\mathrm{m}} \mathrm{m}$. in the University Museum. The Examination for the Burdett-Coutts Geological Scholarship will commence on March 3 at ro a.m.

Mr. Robert Stockdale, of Giggleswick School, has been elected to a Hastings Exhibition in Natural Science at Queen's College.

CAMBRIDGE:-The following are the words spoken by the Public Orator in presenting Dr. Hans Gadow (formerly of the British Museum), Curator of the Strickland Collection of Birds, for the complete degree of M.A. honoris causâ :-

"Dignissime Domine, Dumine Procancellarie et tota Academia : Anni proximi sub finem (iuvat recordari) fabulam illam Aristophanis qua Aves nominatur cum voluptate maxima prope omnes spectavimus. Hodie vero, ad studia nostra severiora redeuntes, nihil auspicatius esse arbitramur, quam annum novum honore in illum collato signare qui omnium avium genera et naturas quasi propriam provinciam sibi sumpsit explorandam. Illum igitur senatoribus nostris hodie merito adscribimus, qui Pomeraniæ maritimæ in parte orientali a gente antiquissima oriundus in celeberrimis Germaniæ Academiis zoologiæ, palæon tologix, mineralogiæ, studiis operam suam feliciter impendit; qui quarto abhinc anno in Britanniam idcirco est vocatus, ut aves in Museo Britannico conservatas summa cura describeret qui in nostra denique Academia nuper non modo de vertebratis quæ dicuntur animalibus prælectiones habutit doctissimas, sed etiam thesauris nostris ornithologicis custcdiendis cum fructu nostro maximo est præpositus. Inter antiquos quidem avinm a volatu cantuque rerum futurarum omina ducebantur; nos meliora edocti hodie in hoc viro Procancellarii novi auspicii. veram avium scientiam laude debita exornamus, ex initio tam felici omnia fausta in futurum augurati. 'Date candida cives Omina, et inceptis dexter cantet avis.' Vobis præsento virum et de studiis ornithologicis et de Academia nostra optime meritum, Hans Gadow.

Mr. W. F. R. Weldon, B.A., St. John's College, has been appointed Demonstrator of Comparative Anatomy.

Mr. Francis Galton, F.R.S., has been appointed Rede Lecturer for the present year.

Prof. W. J. Sollas, M.A, late Fellow of St. John's College, First Class in the Natural Sciences Tripos, 1873, and Mr. P. H. Carpenter, M.A., Trinity College, First Class in the same Tripos, 1874 , have been approved for the degree of Doctor of Science. The able original works in Geology and Zoology by both these gentlemen are familiar to all students. 
LONDON.-At King's College, Prof. W. Grylls Adams, F.R.S., will continue the course of lectures on Light, and the Scientific Principles involved in Electric Lighting, during the remainder of the session. A course of practical work in Electrical Testing and Measurement with especial reference to Electrical Engineering will also be carried on under his direction in the Wheatstone Laboratory. The lectures will be given once a week-on Mondays, at 2 p.m. - and the Laboratory will be open on Wednesday and Friday from $\mathbf{I}$ to 4 .

\section{SCIENTIFIC SERIALS}

THE monthly parts of the Fournal of Botany for $188_{3}$ contain many useful and interesting papers. Among the more important must be regarded Mr. J. G. Baker's synopsis of the genus Selaginella. This is not yet completed, but already extends to nearly 100 species, many of them now described for the first time. This is understood to be an instalment of a complete monograph by Mr. baker of the Vascular Cryptogams, excluding ferns, a work eagerly demanded by botanists. - The additions to the phanerogamic flora of Great Britain are not yet completed ; and the palm of recent discoveries must be awarded to Mr. Arthur Bennett. In this year's record he describes and figures two, one of them, Potamogeton Griffithii, new to science, from a lake in Carnarvonshire. The other, Naias marina, is a native of the "Broads" of Norfolk. This is rendered more interesting by the discovery, by other botanists, of another species of Naias, N. alagnensis, also during the present year, in Lanca-hire. It is not many years since the genus was first found in Britain; and the only species hitherto known, $N$. flexilis, has been gathered only in Scotland and Ireland.-The structure and distribution of the Characeæ are still engaging attention from Messrs. $H$. and J. Groves and others; and of this cryptogamic order, another species, Chara Braunii, has also been added to the flora of Great Britain.-Mr. H. Boswell also describes two new British mosses, Bryum gemmiparum, from Breconshire, and Sphagnum torreyanum, from Shropshire.Messrs. R. M. Christy and H. Corder contribute an interesting paper on the cross-fertilisation of Arum maculatum.-Numerous other articles and short notices of more local and special interest fill up the number.

THE second part of vol. xiv. of Pringshcin's Falurbücher für zeissenschaftliche Botanik contains two important articles on cryptogamic botany:-Dr. A. Fischer, on the occurrence of crystals of gypsum in the Desmidieæ shows that they are of very wide distribution in the family, as well as in other freshwater algæ such as Spirogyra, though by no means universally present. He believes it to be simply a product of excretion in the process of metastasis, whether present in the form of crystals or dissolved in the cell-sap. Dr. O. Muiller, on the law of cell division in Melosira arenaria, offers an important contribution to the life-history of the diatoms. By a most careful series of observations he establishes the law that "the larger daughtercell of the $n$th generation divides in the following or $(n+1)$ st generation, while the smaller daugbter-cell always divides only in the $(n+2)$ nd generation," by an argument which is too long to go into here. He deduces from this law the reason of the comparatively rare occurrence of the auxospores, by which the original size of the species is restored after the continued degradation which it necessarily undergoes in the process of division.-B. Fritsch contributes al:o a paper on coloured granular constituents of the cell-contents.

THE second part of vol. iv. of Enpler's Botanische Fahrbiecher for 1883 contains a continuation of its very valuable review of the more important works on systematic and geographical botany which appeared in 1882. - The other papers are :-By T. Wenzig, on the genus Fraxinus. -By F. Moewes, on hybrids of Mentha arvensis and M. aquatica.-By E. Warming, on the order Podostemacere.

Archives of the Physical and Natural Sciences, Geneva, December 15, 1883.-Meteorological résumé of the year 1882 for Geneva and the Great Saint-Bernard, by M. A. Kammermann, Assistant-Astronomer.-On the ancient lake of the Soleure district (coloured map), by M. Alph. Favre. The existence of this lacustrine basin confirms the conclusion arrived at by other geological studies, that during the early post-Glacial epoch a far gre-ter portion of Switzerland was under tater than at present.
-Descriptive notice of the meteorological observatory installed on September I, 1882, at Sentlis, canton of Appenzell, 2467 metres above sea-level.-On the periodical oscillations of the ground, determined by the spirit-level (fifth year, $1882-\gamma_{3}$ ), by M. P. L. Plantamour.-On the theory of dynamo-electric machines, by M. R. Clausius. These machines having in their practical development outstripped the theory of their construction, an attempt is made in this elaborate paper to expound a theory more in harmony with the results already obtained than are any of the mathematical formulas hitherto employed to represent them.

Rendiconto of the Sessions of the Accademia delle Scienze di Bologna for the year 1882-83. Nov. 19, 1882.-Memoir on the " null envelopes" of the second class in a given system of points affected by given coefficients, showing how, from the general formula, others may be deduced, rendering more evident the property of the envelopes, and solving some questions connected with the momenta of the second order of said system, by Prof. Ferdinando P. Ruffiani.-On three sicephalous monsters, and more particularly on the seven-month Janus recently born in Bologna, by Prof. Luigi Calori.--Note on the extremities of the motor nerve fibres in the striated muscles of the torfedo (Tor pedo marmorata) treated with bichloride of gold and cadmium, by Prof. G. V. Ciaccio.-Microscopic researches on the traces of electric sparks incised on glass, by Prof. Elmilio Villari.On the electric figures of condensers, by the same author.

November 26. - A systematic classification of the genus Puccinia, by Prof. Cocconi and Dr. F. Morini.-On a case of hypertrophic hepatitis, by Prof. C. Taruffi.-Symptomatic and anthropometric studies on the cretinism prevalent in the Valle d'Aosta, Piedmont, by the same author.-Some new researches on the artificial reproduction of the spleen, by Prof. Guido Tizzoni.-On the results of the measures hitherto adopted to improve the soil and climate of malarious districts in Italy, by Dr. Paolo Predieri. - A new contribution to the study of Addison's disease, by Prof. Ferdinando Verardini.

January 14, 1883.-On a fossil cetacean (Orca cetoniensis) recently discovered at Cetona in Tuscany, by Prof. G. Capellini. -A study of some reactions of phosphuretted hydrogen gas, by Dr. Alfredo Cavazzi.

January 28. - On a rapid method for determining the lunar motions, by Prof. A. Saporetti.-New researches on the anatomy and pathology of the placenta in mammals, by Prof. G. Escolani.

February 1r.-Notes on the history of geodesy in Italy from the earliest times down to the second half of the present century, by Prof. P. Riccardi.-Experimental researches on the hypertrophy and partial regeneration of the liver, by Dr. V. Colucci. -On the relative length of the neck in both sexes, and on the best method of making these anthropometric measurements, by Dr. G. Peli.-On the preventive inoculation of contagious pleuro-pneumonia for cattle by means of intravenous injection of the virus, by Prof. A. Gatti.-Anatomical researches on five bovine monstrosities, by Prof. G. P. Piana.

\section{SOCIETIES AND ACADEMIES LONDON}

Royal Society, January 10.- "Experimental Researcbes on the Electric Discharge with the Chloride of Silver Battery." By Warren De La Rue, M.A., D.C.L., Ph.D., F.R.S., and Hugo Müller, Ph.D., F.R.S.

Plasticity and Viscosity of Strata.-During our experiments we have often been struck by the evident plasticity of strata u hcse form at times becomes modified when they meet with an ol stacle or are influenced by other causes, as, for example, the crcssing of other strata produced by a separate discharge.

One of our tubes, No. 9 , with a residual hydrogen vacuum, has a diaphragm in the centre $\frac{1}{4}$ of an inch, $0^{\circ} 63 \mathrm{~cm}$., thick, through the centre of which there is a hole $\frac{1}{4}$ of an inch, $0.63 \mathrm{~cm}$., in diameter. To the end of the tube is attached a potash absorption chamber, the heating and cooling of which causes a change in the number of strata; when the number of strata increases they approach closer and closer to the diaphragm, and occasionally one threads itself through it, as if squeezed through, and its form is gradually changed thereby.

A tube, No. 368 , Fig. I, with a hydrogen residue gives evidence of the vi ccsity of a stratum. 